\title{
Innovation of Ideological and Political Education in Higher Vocational Colleges on the Basis of New Media Platform
}

\author{
Xiaoping Ran \\ Chongqing Real Estate College, Chongqing, China
}

Keywords: New Media, Higher Vocational Colleges, Ideological and Political Education.

\begin{abstract}
In the new media era, new media equipment is necessary for the daily study and life of college students. New media technology has significant impacts on college students' ideas, as well as their learning styles and habits; it also provides a feasible platform for the reform and innovation of ideological and political education in higher vocational colleges. With the innovative education channels offered by the new media technology, the education environment of ideological and political courses in vocational colleges can be optimized, so as to make these courses more realistic and energetic, and further improve the effectiveness of ideological and political education. In this way, the work of ideological and political education in higher vocational colleges can be promoted under the new situation.
\end{abstract}

\section{Present Situation of Ideological and Political Education in Higher Vocational Colleges}

At present, several problems exist in the ideological and political education in higher vocational colleges. Teaching contents are not closely related to students' daily life; only a few of students listen to lectures attentively; teachers and students do not have strong sense of gain; the effectiveness of curriculum is low. To certain extent, these problems dampen the enthusiasm of teachers and students, and weaken the educational functions of ideological and political courses.

\subsection{Curriculum arrangement of ideological and political education}

The content of teaching materials, which is divorced with the times and reality, is the first problem exists in the curriculum arrangement of ideological and political education. Some contents even do not comply with the actual theoretical research. These textbooks do not closely relate to characteristics of the new media era, or practical problems in the reality; they are rootless. The second problem is the teaching style and method, which should be better integrated with practical problems. Take the course of Basic Principle of Marxism as an example. Although some contents in the course need to be imbued to students, Marxism theory should be used to analyze practical problems, which requires teachers to combine teaching content with the reality and epoch topics. The third problem is the class capacity. In most vocational colleges, students from several classes are required to attend the same ideological and political lectures together. With one or two hundred, or even more students sitting in the classroom, discussions are difficult to be carried out. Students cannot be fully motivated and participate in classes.

\subsection{Characteristics of students in higher vocational colleges}

First, the level of vocational school students is relatively low. They have relatively weak learning and acceptance abilities and poor knowledge structure, which brings certain difficulties to the development of new media ideological and political education. Second, students in vocational colleges do not have good learning habits or initiative of learning theoretical knowledge. Ideological and political courses cannot attract their attentions at all. Passing the examination is their only target. Some students are even absent from the class, or taking more time in chatting, playing games, online shopping and ordering takeout. In ideological and political courses, few students listen to lectures attentively. 


\subsection{Negative influences of the new media era}

With the development of new media, an open platform with low threshold of dissemination is established. Everyone can be the publisher of information on that platform. While bringing convenience to people, new media platform also spread bad information which may cause students' ideological confusion. With the emergence and popularity of computers, Internet and instant communication tools, Western values are also imported into university campus through advanced network technology; the fight of competing for the right of speech and seizing the public opinion fields is launched. Students in higher vocational schools are inexperienced and do not have mature thought. They are lack of initiative of accepting theoretical knowledge, but they have strong skills on new media equipment using, and can accept information fast. Thus, they are easily influenced, or even brainwashed by Western values, which brings a great challenge to the education of Chinese ideological and political values, and seriously affects the value guide function of ideological and political courses in higher vocational colleges.

\subsection{The combination of traditional teaching and new media is not strong enough}

New media equipment provide a lot of convenience for colleges and universities to carry out ideological and political education; but currently, some problems exist in the using of new media. Many colleges and universities have combined ideological and political courses with the new media, but what they have done is uploading the traditional teaching content to the Internet. There's no innovation in teaching content or teaching methods generated from the characteristics of students and the new media era. Some colleges are trying to teach traditional content through the new media platform, but due to shortcomings such as hardware backwardness, lacking of professional personnel, low levels of student and new media technology utilization, there are great differences between foundations of network ideological and political education in colleges and universities.

\section{Innovation and Transformation Faced by Ideological and Political Education in the Era of New Media}

In the new media age, characteristics of new media such as immediacy, interaction, openness and mobility can be fully used to enrich the contents of ideological and political education, and create new transmission modes.

\subsection{It helps ideological and political educators to improve their working efficiency quickly and effectively}

The new media platform includes QQ, WeChat, micro-blog, video, SMS and other communication tools. They are two-way interaction methods; participants are both disseminator and recipient of information. Users can interact with each other through text, voice, video and other multimedia means. These tools have advantages of simple operation and complete function, and can greatly reduce the transmission cost of spreading ideological and political education information, as well as the burden of ideological and political education. They can also improve the efficiency and effectiveness of ideological and political education, and open up a new space for the ideological and political education.

\subsection{Educators and students can communicate in real time through network platform}

Traditional ideological and political education often adopts the method of one-way indoctrination. Teachers impart ideas and moral norms required by the society to students, ignoring the needs and receiving abilities of students. This method inhibits the enthusiasm, initiative and creativity of students. In the era of new media, the ideological and political education should become a communication process of ideology and emotional consciousness based on the interaction of teachers and students. 


\subsection{It helps to break the space limitation of ideological and political education}

On the Internet, the processing of information media is not limited to transmission, reception, browsing and storage of some fixed terminals. With the development of wireless technology in the new media era, people can access the Internet, receive and send information anywhere and at any time. It breaks the traditional mode of fixed space. Students can accept information about ideological and political education in any place.

\subsection{It is conducive to the transformation of communication mode of online ideological and political education}

The Internet is the product of information age. It has characteristics of big information carrying capacity, the combination of pictures, videos and sound, strong interaction, convenient operation and rapid retrieval. In the new period, ideological and political education develops vigorously. The function of network in ideological and political education has gradually been admitted. More and more educators choose to carry out ideological and political education through the network platform, and establish related websites. People began to think about how to change from passive defense to active construction. The new media has become a kind of mass media with strong vitality, which has brought profound influence on ideological and political education.

\section{The New Media Platform Can Greatly Improve the Effectiveness of Ideological and Political Education}

New media brings challenges to traditional ideological and political education, and becomes an important medium for some western countries to infiltrate ideology. The traditional mode of ideological and political education and the authority of educators are challenged. The immediacy, interactivity and mobility of the new media also provide a great opportunity for the innovation of content and communication method of ideological and political education. Ideological and political educators should seize this opportunity to realize the innovation and upgrading of ideological and political education, combine the characteristics of higher vocational school students with the new media era, actively change their ideas to fully understand and grasp the favorable opportunity brought by the new media, and explore new education methods in the new media environment, so as to improve the effectiveness of ideological political education.

\subsection{New media has become an important carrier of ideological and political education}

First, higher vocational colleges construct various forms of teaching platform for ideological and political education, trying to maximize the educational function of ideological and political work through the communication advantages of new media network. Second, a small number of institutions hold online education activities like theme class meetings, in order to help students to tell and discard bad information disseminated on the Internet. Information on the new media network is open and transparent; it can basically meet students' needs of independent choice. But students also need correct self cognition in their ideological construction activities. Third, most ideological and political educators in vocational colleges can actively respond to new media online teaching, learn theory and knowledge of new media technology constantly, and innovate the teaching content and methods of ideological and political education through the new media platform.

\subsection{Improving the media literacy of ideological and political theory teachers}

New media is one of the most active, advanced and rapid spread social production tools and the way of life. The traditional teaching mode is unable to resist challenges in teaching method reform brought by the new media era. New media technology provides new conditions for college ideological and political education, and brings great challenges to the traditional ideological and political theory education. Under that background, ideological and political theory teachers should not only understand the characteristics of new media, but also adapt to the new media environment, learning and using the latest technological achievements and new media platform, grasping the 
characteristics, laws, as well as the development trends of new media, and improving their media literacy.

\subsection{Innovating the channels of ideological and political education with the help of new media technology}

The main channel of ideological and political education in higher vocational colleges is classroom teaching. To improve the effectiveness of teaching, the advantages of new media must be fully used. The scientificity, artistry and ideology of ideological and political theories must be combined to improve the persuasiveness and attraction of ideological and political education contents.

Using new media to innovate the theory content of ideological and political education. With the help of new media, we can grasp the ideological trend, learning situation and daily life of students. Thus, the teaching contents of ideological and political education can be innovated according to the actual needs of students. Ideological and political education in higher vocational colleges must be continuously improved, and focus on the latest and hottest practical problems, in order to solve the practical problems accurately and timely, attract students' attention and improve their learning enthusiasm.

Using new media to innovate the teaching methods of ideological and political education. New media can be used to learn students' ideological confusion, understand interesting topics and social concerns. By introducing ideological and political hot points, as well as social issues into classroom discussion, teachers can mobilize the classroom participation, arouse students' enthusiasm of using Marxism theory, and strengthen the effective communication, as well as the interaction between teachers and students.

The classroom teaching is extended to network space with the help of new media platform. Ideological and political teachers can upload teaching content and reference materials to the Internet. Students can learn these materials at any time; the efficiency of classroom teaching can be improved.

Creating more social practice forms for teachers through the new media platform. At present, the ideological and political teaching in many universities did not realize everyone's participation. Micro-blog, WeChat and other new media communication tools can be used to easily accept and share other's social practice experience at anytime and anywhere.

\subsection{Optimizing the ideological and political education environment in higher vocational colleges with the help of new media platform}

The new media environment ensures the timely communication between teachers and students. The no barrier interaction platform is provided for teachers and students. Through the education and guidance of positive energy, correct life values, positive attitudes and healthy thoughts, schools can optimize the new media environment and help students to establish correct outlook on world, life and values. Higher vocational colleges can also establish campus BBS with the help of new media platform. On this platform, students can express their real ideas and suggestions; school authorities can grasp students' ideological trend and respond to their reasonable demands in time. With the rapid development of science and technology, the campus FTP, which has been persistently purified and managed for many years, has become the most valuable and concerned network space in multimedia learning, and is favored by college students.

\subsection{Increasing the attraction of ideological and political education with the help of new media}

The increasing of attraction and enthusiasm of ideological and political education requires high-quality classroom teaching; but only classroom teaching is not enough. The key to activate students' dominant role is to improve teaching quality. Apart from classroom teaching and discussion, ideological and political courses also include pre class preparation, answering questions after class, as well as extracurricular practice. The whole education process cannot be completed without the links of before, during and after the class, inside and outside of the classroom, as well as the online teaching and offline teaching,

First, before the class, teachers release teaching content through the new media platform and activate the dominant position of students. Second, during the class, teachers can set problem 
situations and guide students to think and solve the problem independently. Applying knowledge and materials they have learned, students should be able to put forward to solutions. Combing asking questions and solving problems, as well as reasoning and storytelling process together, the teaching content can become more appealing. Third, before the class, the teacher can organize students to visit patriotism education bases. Combing history, theory and reality together, the attraction of teaching content can be increased. With these methods, we can continuously enhance the value guidance and educational functions of ideological and political education in higher vocational colleges.

In the new media era, ideological and political education is facing the innovative transformation. It is the requirement of improving the efficiency of ideological and political education; it helps to unite the younger generation, integrate multiple ideas, and promote the internationalization of communication pattern. Teachers' new media using abilities are related to the attraction power of lectures. School authority should add new media using into the training and evaluation system of ideological and political teachers, so as to enhance the new media literacy of ideological and political teachers. Under the impetus of continuous innovation and deepening reform, ideological and political education will have a broader prospect with the help of new media development.

\section{Acknowledgements}

Foundation for Humanities and Social Sciences Projects of Chongqing Province.

\section{References}

[1] G.Q. Sun, T. Liu, Influence of the new media on college ideological and political education, J. Reform \& Openning. 8 (2011).

[2] Y.J. Zheng, J. Journal of Ideological and Theoretical Education. 11 (2011).

[3] M.H. Zheng, Approach of improving college ideological and political education under the background of new media, J. Theory Research. 5 (2015).

[4] J.P. Xi, Speech at the National Conference of Ideological and Political Education in Colleges and Universities, xinhuanet, December 8, 2016. 